\title{
We Need Stories and Bibliotherapy Offers One Solution to Developmental Issues
}

\author{
Pirjo Suvilehto* \\ Department of educational sciences, University of Oulu, Finland
}

*Corresponding author: Pirjo Suvilehto, Department of educational sciences, University of Oulu, Finland.

Received Date: July 04, 2019

Published Date: July 31, 2019

\begin{abstract}
The power of stories, that is, bibliotherapy and literary arts, lies in the field of literature and in the knowledge of new ways to gain wellbeing and joy through literary practices, specially, in education. In this short paper I discuss about the benefits of developmental bibliotherapy, which means active interaction with a child through a story and its fictional characters. A well-chosen and an appropriate book may be a solution for many daily concerns $[1,2]$.
\end{abstract}

Keywords: Bibliotherapy; Children and adolescents; Literature, Drama education

\section{Introduction}

The objective of this short Opinion writing is a modest demand for scientific renewal of the early phase of my doctoral research [3] and my academic writings after that until 2019. Bibliotherapy in an educational context for children and adolescents is a resource that is not enough well known among teachers. My aim is to produce and distribute knowledge of the ways in which literature and literary arts can be practiced as a means of bibliotherapy, especially in educational contexts. My intention is to develop a cost-effective method of university level education, and to broaden the concept of literature in the mentality of wellbeing e. g. with the method of Pritney TM. Thus, the concept of bibliotherapy and its inherent potential will be transferred into practice on an educational level (universities), in childcare, kindergartens, pre-schools and in schools along with our national project called Hand in Hand.

\section{Discussion}

Literature has a positive impact on a child's development and wellbeing [4,5] and bibliotherapy is an under-used resource in the field of education. The combination of children and bibliotherapy is significant in a world, where literary skills are ever more needed, and I do not mean the importance to gain merely practical reading skills. Bibliotherapy is a therapeutic approach that uses literature (poems, stories, creative writing etc.) to support mental health. Literature may be used for healing and personal growth and be traced back to primitive man in religious rites, where poetry was used for the wellbeing of the tribe or individual. Literature as a healing method dates also back to ancient Greece. In short, bibliotherapy means books and other literature to serve and help (NAPT-The National Association for Poetry Therapy). It means access to benefit from reading skills, but also to experience the joy of reading. It is well documented that stories and literary activities in children's lives have diverse positive effects and by using carefully selected thematic books teachers can use literature to reach out to students experiencing difficult situations $(6,2)$.

Many teachers in day care and at school practice bibliotherapy in some manner, often without giving their practice a formal name. However, effective follow-up activities, thoughtful questions, and focused discussions require that teachers are mindful about their use of books to address individual and group issues [7]. Teachers are attempting to help students with socio-emotional difficulties, and school professionals are searching for ways to promote skills and adjustment (8). Collaboration between psychologists and educators may be beneficial with bibliotherapy as a tool. There are methods related to bibliotherapy which are available. These methods enable discussions and provide guidelines for practice [9,10]. There are web-pages encouraging families to have important bookreading sessions' in children's everyday lives [11,12]. However, systematic in-depth studies on how books may be beneficial as 
bibliotherapeutic means in challenging situations in educational contexts in kindergartens, schools, or at university are still missing. Although, there are studies on practices in classrooms concerning developmental bibliotherapy (13), the current knowledge is often based mostly on reading skills, while babies' books and reading habits have been particularly ignored $[14,15]$.

There have also been concerns regarding children's diminishing reading skills [10]. Additionally, there has been a concern about the growing emotional problems in families and with children in schools, and teachers are finding bibliotherapeutic activities to enhance their wellbeing [16]. Some examples of this include a 10 -step process for implementing bibliotherapy in the classroom and providing samples of juvenile books used in bibliotherapy. Responding to these issues, changes need to take place in ways that support meaningful child-reading relations, and sensitive child adult relations. For this to be possible there is an urgent need to know

- What kinds of books and reading sessions are significant to children, but also

- How it is possible to implement bibliotherapeutic reading sessions and interaction with children as part of their everyday lives.

Studies on bibliotherapy, especially academic research into children's bibliotherapy, and the beneficial use of books in early childhood settings in shared everyday lives are, however, are extremely rare, not only nationally but also internationally.

The disciplinary backbone of my scientific and academic work comprises educational science, literary studies, cultural anthropology and the multidisciplinary fields of posthuman studies and animal studies, childhood studies and psychology. All of the mentioned disciplines are areas in which children's literature may be used as a vehicle for development and may even involve healing practices and meanings. In particular, affective bibliotherapy even seems to be superior to cognitive bibliotherapy [4] for children, and thus emphasizes the importance of the emotions, effectiveness and sensitivity of adults during reading sessions [17]. The societal significance of the research is anchored in serious consideration of children's and adolescents' bibliotherapy and how we may benefit from it on many levels in our society. There is an urgent need for valuable academic research to raise a wider consciousness of bibliotherapy. The research is also valuable for its practical goals in implementing good practices and recommendations to be shared between child health care centers, kindergartens, pre-schools, and schools. A focus on bibliotherapy as "healing words" is an acknowledgement of children as capable, complete, equal citizens and also productive members of society. Children are people who have their own thoughts, imagination, understanding and creativity. Educators, teachers and parents need new vehicles to cope with challenges of wellbeing with children and families in our changing societies. Children have their rights to a good life and to many good daily practices, e.g. at home and, at school and in day care. Making reading a daily, enjoyable routine may be one thing to enhance children's wellbeing by listening to, what a child is interested in, and to understand, what developmental tasks she/he is going through at the moment [18]. Finnish curriculum of early childhood education and care [18] is based on an integrated approach to care, education and teaching (the Edu care model), and learning through play is seen as essential.

Finland is a unique and timely context in which to study children's bibliotherapy, as our country is well known from its good educational practices and children's reading skills. We have a long history with a school library system, and it is well known that Finnish people like to read [19]. So, the assumption is, that reading is part of everyday practices in various areas. The question is, how to maintain the attraction and enchantment of creative reading, and to ensure that educators have good knowledge of the many possibilities brought forward by books and literature which are central in bibliotherapy. Stories may be powerful tools to maintain and enhance wellbeing on an individual and societal level [20]. The relatively independent habit of reading among children in general, in both urban and in rural everyday environments, is internationally renowned [21]. However, there is an increasing concern for children who face serious challenges in their everyday lives, and who have no emotional access to stories, or enjoyable reading moments, and there is a need to encourage families to create reading moments. Additionally, in kindergartens, pre-schools and schools, encouragement is needed to develop good reading skills. Furthermore, as with the idea of bibliotherapy, especially among children and adolescents, preventative, developmental, and interactive bibliotherapy have special tools for adults to maintain wellbeing and enhance joy among children, who have many developmental tasks to conquer.

\section{Conclusion}

Previous research on bibliotherapy and children's relations with books: To summarize, the findings of my previous research (1$3,14,15,22-25)$ indicate that

- $\quad$ Bibliotherapy has applications in many contexts, also in children's lives,

- $\quad$ There is international concern regarding diminishing reading skills of children, and that

- Children's and adolescents' (developmental) bibliotherapy are not enough well known among parents, teachers, and educators as a vehicle to create and sustain reading sessions and reading habits, which are significant in children's' daily lives.

Without knowledge of children's views, child-book relations often end up being ignored, or valued or only for their utility towards children's future development rather than their everyday well-being. Of the research conducted related to children's reading skills, until recently virtually the entire focus was on children's development from an adult point of view. Studies seem to locate in the field of education and assess the usefulness of reading skills towards children's development. Of these studies, a further majority 
focus on scaffolding, or the use of new media in improving children's educational skills. Caring, companionship, security, comfort, amusement and joy are items which are essential to developmental and preventive bibliotherapy, and these are the major focus of this Opinion writing. Studies into disciplinary frameworks of children' s bibliotherapy on an educational level are drastically fewer in numbers and arise mostly from the fields of social sciences, medical science and psychology [26]. The benefits of "power stories" in the everyday life of "healthy" children to enhance their wellbeing in situational and developmental tasks need to be studied.

Studies on child-book relations, within educational sciences in particular, can explore the usefulness of picture books especially in pre-primary education and children's literature in formal education. Questions which have profound implications for society are virtually unexplored, e.g how student kindergarten teachers can and practicing teachers handle the ever-increasing developmental tasks in the growing multi-cultural contexts of children, e.g. in children's everyday places such as day care and schools.

At the moment I am working in a national project called Hand in Hand, funded by Finnish Ministry of Education and creating my Pritney Method, which brings forth a concept from bibliotherapy [27], approaching child-book relations from the viewpoints of children in their daily lives, and how books and literary art focused activities have the power to enhance children's knowledge of themselves, to bring joy and build trust in the future. As in educational settings, this concept is referred to as developmental bibliotherapy and may be used by teachers, librarians and parents, and is meant to help children grow and develop [28-31]. In particular, this project has a special interest also in infants, and how literary arts may be practiced with infants, as well as how parents may be sensitive with their babies and create interaction with rhymes, first books and joyful moments in stories. Especially, pictures that are aimed at infants and their families are lacking evidence in academic research $[32,33]$. Theoretical-methodological approaches situated in literature studies, childhood studies, in addition to emerging approaches under 'post humanism' and psychoanalysis, such as the work of scholars including Freud, Winnicott, Mazza and Pennebaker contest the notion of literature and its benefits in multiple cultural contexts.

\section{Acknowledgement}

None.

\section{Conflict of Interest}

\section{No conflict of Interest.}

\section{References}

1. Suvilehto P, Ebeling H (2008) Literary therapy to support the development of children and adolescents. Duodecim 124(5): 27-33.

2. Suvilehto P (2019b) A study of animal characters as representations of humans: the animality/bibliotherapy test. Journal of Poetry Therapy 32(2): 95-108.

3. Suvilehto P (2008) Creative writing as an opener of children's emotional blocks. A case study of the writings of children aged 8-13 attending the Northern Finnish Hospital School and the Main House Institute.
Children's Creative Writing as the Opener of a Mental Plug: A Case Study of the Writings of 8-13-Year-Old Children in a Northern Finnish Hospital School and the Main House Institute.

4. Betzalel L, Shechtman Z (2010) Bibliotherapy Treatment for Children with Adjustment Difficulties: A Comparison of Affective and Cognitive Bibliotherapy, Journal of Creativity in Mental Health 5(4): 426-439.

5. Kümmerling Meibauer B (2011) Emergent literacy and children's literacy. Emergent literacy: Children's Books p: 1-14.

6. Mihić SS, Maich K, Belcher C, Perrow S, Barišić A, Ramić NN (2017) The role of bibliotherapy and therapeutic storytelling in creating inclusive classroom communities. In: Handbook of Research on Classroom Diversity and Inclusive. Petersen, Amy J (eds.), Hershey, PA, USA: IGIGlobal pp: 375-398.

7. Fries Gaither J (2017) Bibliotherapy: Helping Students, One Book at a Time.

8. Sullivan AK, Strang HR (2002) Bibliotherapy in the Classroom Using Literature to Promote the Development of Emotional Intelligence. Childhood Education 79(2): 74-80.

9. Lucas CV, Soares L (2013) Bibliotherapy: A tool to promote children's psychological well-being. Journal of Poetry Therapy 26(3): 137-147.

10. Joy of Reading (2019).

11. Shah (2019) Book therapy.

12. Stewart AE (2017) Reading and storytelling with babies and children Raising children Network.

13. Catalano A (2008) Making a Place for Bibliotherapy on the Shelves of a Curriculum Materials Center: The Case for Helping Pre-Service Teachers Use Developmental Bibliotherapy in the Classroom. Education Libraries: Children's Resources 31(1): 17-22.

14. Suvilehto P (2019a) Human-Animal Interaction at the Stable: Observations of an Infant's Pony and Bunny Contacts and Literary Arts in a Case Study. The international journal of arts education 14(1): 15-33.

15. Suvilehto P (2014) A book as a tool for growth-first books in Finnish in the 1970 and 2010. Journal of Early Childhood Education Research JECER 3(2): 2-26.

16. Prater MA, Johnstun ML, Dyches TT, Johnstun MR (2006) Using Children's Books as Bibliotherapy for At-Risk Students: A Guide for Teachers. Journal of Preventing School Failure: Alternative Education for Children and Youth 50(4): 5-10.

17. Bus AG (2003) Joint Caregiver-Child Storybook Reading: A Route to Literacy Development. In: Neuman, SB Dickinson, DK (eds.), Handbook of Early Literacy Research 1: 179-191. New York-London: The Guilford Press.

18. Curriculum of Early Childhood Education and Care (2017).

19. BengtssonN (2013) The History of Translation Literature for Children and Adolescents in the $17^{\text {th }}$ and $18^{\text {th }}$ Centuries.

20. Mazza N (2012) Poetry/creative writing for an arts and athletics community outreach program for at-risk youth. Journal of Poetry Therapy: The Interdisciplinary Journal of Practice, Theory, Research and Education 25(4): 225-231.

21. Compton Lilly C (2003) Reading Families: The literate lives of urban children. New York-London: Teacher's College Press.

22. Suvilehto $\mathrm{P}(2017 \mathrm{a})$ Joy of creative writing with Horses. Cases of therapeutic encounters. A horse is a horse, of course-compendium. Part Two (Equines in various Equine Interaction Programs).

23. Suvilehto P (2017) Messengers in the shadow. Creative writing and dreams. Journal of Poetry Therapy 31(1): 56-67.

24. Suvilehto P (2016) Horror and aggression in children's creative writing: implications for bibliotherapy and child development. Journal of Poetry Therapy 29(2): 1-11.

25. Suvilehto P, Latomaa T (2018) Writing with horses: poetry with therapeutic art activities supporting self-expression in a case study. Journal of Poetry therapy 31(1): 1-20. 
26. Marrs RW (1995) A Meta-Analysis of Bibliotherapy Studies. Am J Community Psychol 23(6): 843-70.

27. Mc Chord Crothers S (1916) A Literary Clinic. The Atlantic Monthly Archives pp: 291-301.

28. Ching Yuan Hsiao (2010) Enhancing Children's Artistic and Creative Thinking and Drawing Performance through Appreciating Picture Books. The international journal of Art and Design Education 29(2): 143-152.

29. Mc Culliss D (2012) Bibliotherapy: Historical and Research Perspectives. Journal of Poetry Therapy 25(1): 23-38.
30. Pardeck J, Pardeck, Jean A (1993) Bibliotherapy: A Clinical Approach for Helping Children. Special Aspects of Education (16): Bibliotherapy: A clinical approach for helping children. Amsterdam, Netherlands: Gordon and Breach Publishers.

31. Pierce LM (2015) The Use of Bibliotherapy among Adolescents and their Family. Family Psychotherapy 26(4): 323-330.

32. Rozalski M, Stewart A, Miller J (2010) Bibliotherapy: Helping Children Cope Life's Challenges. Journal of Kappa Delta Pi Record 47(1): 33-37.

33. The National Association for Poetry Therapy. 